\title{
NUTRITION ASSISTANCE PROGRAM EFFECT ON WEIGHT OF CHILDREN UNDER FIVE YEARS
}

\author{
Siti Riptifah Tri Handari, Munaya Fauziah, Mia Endah Asmalasari \\ Faculty of Medicine and Health, University Muhammadiyah of Jakarta
}

\begin{abstract}
Background: Nutrition is a major factor in improving the quality of human resources (HR). The quality of a country's human resources can be measure with nutritional status of children under five year, which is the candidate for the next of the nation generation. Under nutrition rates among children under five in Indonesia according Riskesdas 2007 is $18.4 \%$ (prevalence of severe undernutrition children underfive is $5.4 \%$ and $13.0 \%$ of children underfive undernutrition) and data Riskesdas 2010 is $17.9 \%$ (prevalence of severe undernutrition children under five $4.9 \%$ and $13.0 \%$ of children under five undernutrition. Although the figure has decreased, but the number is still high and has not reached the MDG target of 15.5\% and RPJMN 2010-2014 is $15 \%$. Widespread malnutrition in the community due to multifactorial, but there are two reasons that are believed to be the direct cause of low consumption of food and the presence of infectious disease. The indirect causes are factors of parenting and childcare, food availability also environmental sanitation.

Method: This study aims to determine the effect of nutrition assistance programs during one month of the weight of children under five. The method used is Non-Randomized QuasiExperiment with pre-test and post-test group. Sampling was conducted with a purposive sample of experiments, a total of 15 samples.

Result: Results of Paired T-Test showed that the value of $p<0.005(p=0.001)$. It can be concluded that the nutritional assistance program, which lasted for one month is able to increase weight children under five $(p=0.001)$.

Conclusion: Advice for $\mathrm{PHC} /$ Health Department to address the nutritional problems in children under five is to increase nutrition assistance program through nutritional care of the family.
\end{abstract}

Keyword: nutrition assistance program, weight, children under five years

\section{Introduction}

MDGs (Millennium Development Goals/MDGs) in 2015 put the man as the main focus of development activity which includes all the components that the end goal is the welfare of society. ${ }^{1}$ Nutrition is a major factor in improving the quality of human resources (HR). The quality of a country's human resources can be measure with nutritional status of children under five year, which is the candidate for the next of the nation generation.

Under nutrition in children under five in Indonesia is still a problem, it can be seen from the data of Basic Health Research (Riskesdas) 1989 the prevalence of under nutrition among children under five was $31.1 \%$ (prevalence of severe under nutrition children $7.2 \%$ and $23.8 \%$ under nutrition children), in 2007 the prevalence of malnutrition in children under five was equal to $18.4 \%$ (prevalence of severe under nutrition children $5.4 \%$ and $13.0 \%$ of children under five under nutrition) and in 2010 was $17.9 \%$ (prevalence of severe under nutrition children $4.9 \%$ and $13.0 \%$ of children under five under nutrition).

Although these data indicate a decrease in the prevalence of under nutrition and severe under nutrition than the previous year, but their numbers are still quite high, and the prevalence is still above the target of the National Medium Term Development Plan (RPJMN) from 2010 to 2014 which is $15 \%$ and the MDGs by 2015 which is 
$15.5 \%$. To achieve the target, the national prevalence of malnutrition should be lowered at least by $2.4 \%$ in the period $2011-2015$.

However, Indonesia has committed to synergize RPJMN with the MDGs 2010 2014 which is a global and national commitment to improve the well-being and the health of the community by the community nutrition acceleration strategy. Malnutrition in infants caused by multi factorial the direct causes of malnutrition is the low consumption of food and the presence of infectious disease. Low consumption of food is generally a syndrome of poverty, and the incidence of infectious diseases is a reflection of poor environmental sanitation. ${ }^{2}$

\section{Research Objective}

The purpose of this study was to determine the effect of nutrition assistance on body weight of children under five in selected areas of Sub-District South Gandaria RW 07, District Cilandak, South Jakarta in 2013.

\section{Benefits of Research}

The results of this study can be used as an input for the problem of malnutrition prevention programs, especially in the area of South Gandaria.

\section{Research Methodology}

The design of this study is Quasi Experimental with Non- Randomized pre-test and post-test group performed for one month in March 2013 in selected areas of SubDistrict South Gandaria RW 07, District Cilandak, South Jakarta.

The population in this study were all children under five (ages 12 months to 60 months) in Posyandu (Integrated Health Services) Bahari the $1^{\text {st }}, 2^{\text {nd }}, 3^{\text {rd }}, 4^{\text {th }}$, and the $5^{\text {th }}$ in RW 07 South Gandaria, which weight listed below the red line (BGM), yellow and it didn't go up until two times respectively (2T) according to Health Card (KMS) on the cadres record, as well as all children under five with yellow or red signs according to Health Card that came on inspection and weighing by Rumah Zakat (a social organization) in RT 014 RW 07. Samples were taken with quota sampling, which amounts to 15 children under five who were taken purposively. The flow of the study as follows:

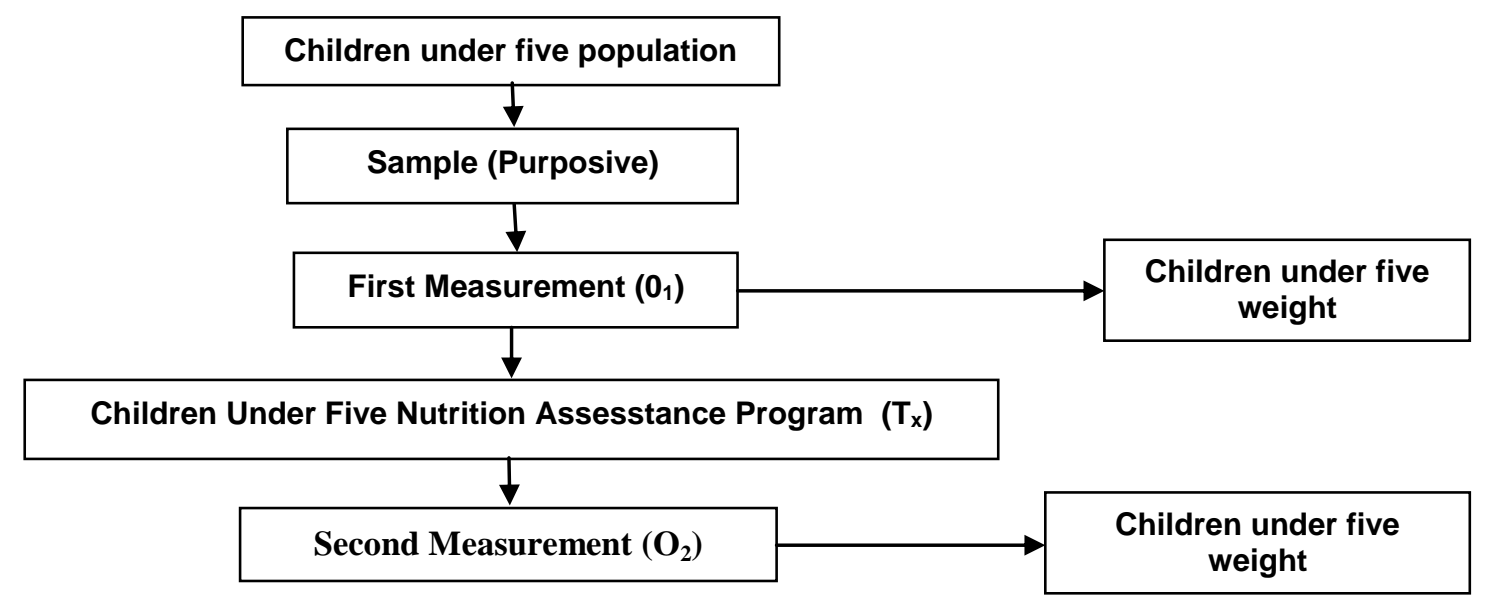

Figure 1. Research Flow 


\section{Nutrition Assistance Program}

Nutrition Assistance Program is providing support and services activities for mothers about nutrition and children under five health care that includes children's eating pattern, children's hygiene pattern, children's health care to the mother /child caregiver assistance. The stages are as follows:

1. Intensive = day 1 - day 7 , three times assistances in a week, in the form of two times meetings and one time visits by researchers (monitoring and counseling practice of child nutritional care), with giving supplementary feeding (PMT).

2. Strengthening = day 8 - day 14 , two times assistances in a week, one time visit by researchers (monitoring and counseling practice of child nutritional care) and one time meeting for counseling and cooking together (monitoring parenting practices), weighing children under five weight (monitoring children weight during the program), with giving supplementary feeding (PMT).

3. Independent = day 15 - day 26 cooking competition (creativity assessment upbringing) also with giving supplementary feeding (PMT).

Visits from cadres to distribute supplementary food (PMT) conducted every day, every afternoon in accordance with the instructions Ministry Of Health RI (2011) on the PMT - P BOK. Giving supplementary feeding directly (on side) by looking at the child while eating PMT.

If the children under five's mother or caregiver do not follow the nutrition assistance in a group (counseling, cook together, and contest) then the child does not get PMT. Below is an example of the PMT is given to children under five:

Table 1. Examples of Food Supplement

\begin{tabular}{ccc}
\hline No & Day 1-7 & Type of Food * \\
\hline 1. & Monday & Boiled eggs + watermelon \\
2. & Tuesday & Braised Chicken + melon \\
3. & Wednesday & Complete Vegetable soup ( meatball , quail eggs etc $)+$ \\
& & papaya \\
4. & Thursday & Biscuits + milk + banana \\
5. & Friday & Mung bean porridge+ melon \\
6. & Saturday & Meat patties + Pear \\
7. & Sunday & Rice flour porridge+ papaya \\
\hline & ${ }^{*}$ Each child received one piece (fruit) and one portion (food)
\end{tabular}

Additional food items which are eligible:

a. Derived from local groceries. If the local grocery limited, additional food can be packaged food with attention to packaging, nutrient content and expiration date.

b. Supplementary food is not a substitute for daily regular diet children under five.

c. Supplementary food for children under five preferred of animal and vegetable sources of protein (e.g. eggs/ fish/ meat/ chicken, beans or exchange) as well as a source of vitamins and minerals which are mainly derived from vegetables and local fruits. 


\section{Research Outcomes}

1) Characteristics of Samples

Table 2. Frequency Distribution Based on Sample Characteristics Nutrition Assistance Program

\begin{tabular}{lcc}
\hline \multicolumn{1}{c}{ Sample Characteristics } & $\begin{array}{c}\text { Frequency }(\mathbf{n}) \\
\mathbf{n}=\mathbf{1 5} \text { Percent }\end{array}$ & $\begin{array}{c}\text { Persentase } \\
(\%)\end{array}$ \\
\hline Sex & & \\
Male & 4 & 26.7 \\
Women & 11 & 73.3 \\
\hline age & & \\
12 months -24 months & 2 & 13.3 \\
25 months -59 months & 13 & 86.7 \\
\hline
\end{tabular}

2) Characteristics of the Sample's Family

Table 3. Frequency Distribution Based on Children Under Five Caregivers

\begin{tabular}{lcc}
\hline Characteristics & $\begin{array}{c}\text { Frequency }(\mathbf{n}) \\
\mathbf{n = 1 5} \text { Percent }\end{array}$ & $\begin{array}{c}\text { Persentase } \\
(\%)\end{array}$ \\
\hline - Raised by the biological mother & 1 & 73.3 \\
- Not raised by the biological mother & 4 & 26.7 \\
\hline
\end{tabular}

The above table shows that most children under five cared for by their biological mother (73.3\%). Addition to see if the children cared for by someone other than the mother, researchers also looked at the characteristics of the mother/caregiver and the characteristics of the father/guardian, such as age, education and also job. The data in Table 4 below show that the age of the families involved in this study largely classified as productive (age below 50th) with a value for the father /guardian as much as $100 \%$, and the mother/caregiver as much as $86.7 \%$.

Table 4. Frequency Distribution Based on Characteristics of the Sample

\begin{tabular}{|c|c|c|c|c|}
\hline \multirow{2}{*}{ Characteristics of The Family } & \multicolumn{2}{|c|}{ the Mother / Caregiver } & \multicolumn{2}{|c|}{ Father / Guardian } \\
\hline & $\begin{array}{l}\text { Frequency } \\
\text { (n) } n=15\end{array}$ & $\begin{array}{c}\text { Percentage } \\
(\%)\end{array}$ & $\begin{array}{c}\text { Frequency } \\
\text { (n) } n=15\end{array}$ & $\begin{array}{c}\text { Percentage } \\
(\%)\end{array}$ \\
\hline \multicolumn{5}{|l|}{ Age Categories } \\
\hline Elderly ( > 60th ) & 1 & 6.7 & 0 & 0 \\
\hline Pre- elderly ( 45 - 59th) Non pre / elderly (< & 3 & 20 & 2 & 13.3 \\
\hline 45th ) & 11 & 73.3 & 13 & 86.7 \\
\hline \multicolumn{5}{|l|}{$\begin{array}{l}\text { Education } \\
\text { - Do not go to }\end{array}$} \\
\hline - Graduated from Elementary School & 2 & 13.3 & 4 & 26.7 \\
\hline - Graduated from Secondary High School & 7 & 46.7 & 2 & 13.3 \\
\hline \multirow{2}{*}{ - Graduated from senior high school or more } & 2 & 13.3 & 1 & 6.7 \\
\hline & 4 & 26.7 & 8 & 53.3 \\
\hline \multicolumn{5}{|l|}{ Job } \\
\hline - Not working & 10 & 66.7 & 1 & 6.7 \\
\hline - Working & 5 & 33.7 & 14 & 93.3 \\
\hline - Labour & & & 3 & 20 \\
\hline - The driver & & & 3 & 20 \\
\hline - Employees & & & 5 & 33.3 \\
\hline - Self Employed & & & 2 & 13.3 \\
\hline - Other (rental of motorcycle) & & & 1 & 6.7 \\
\hline
\end{tabular}

The education level of family more low education ( $\leq$ SMP) with the status of reproductive age with working fathers and mothers as housewives. 
3) Body Weight

Based on the data in Table 5 shows the increase in body weight occurred after nutrition assistance of 0.38 or an increase in body weight of $3.33 \%$.

Table 5. Mean Body Weight (BW) Samples

\begin{tabular}{ccc}
\hline No. & Time Measurement & $\overline{\mathrm{x}} \pm \mathrm{SD}$ \\
\hline 1. & The initial measurements $\left(\mathrm{O}_{1}\right)$ & $11,14 \pm 1,9628$ \\
2. & The final measurement $\left(\mathrm{O}_{2}\right)$ & $11,52 \pm 1,97564$ \\
\hline
\end{tabular}

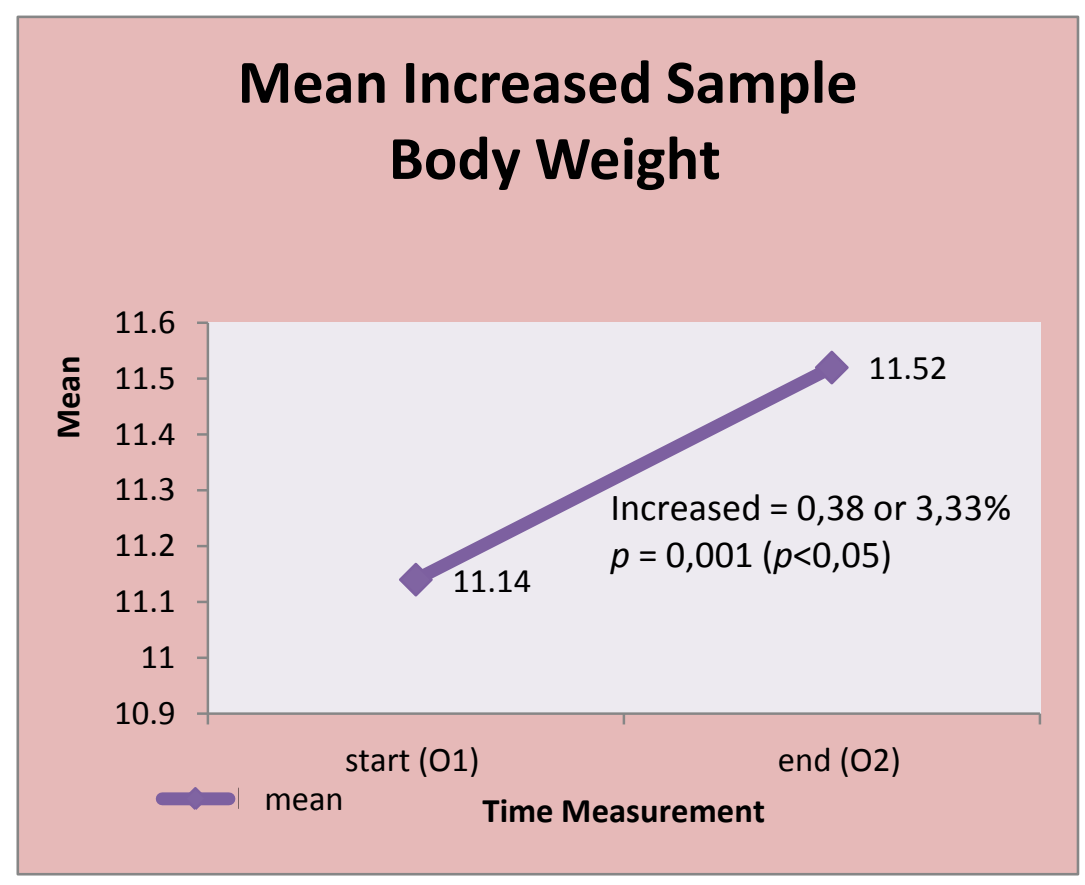

Figure 1. Mean Increase Weight Loss

Furthermore, to determine the level of significance changes in pattern of parenting practices between mothers before and after nutritional assistance can be seen in Table 6 below:

Table 6. Mean Increased Sample Weight

\begin{tabular}{ccccc}
\hline No. & Time Measurement & $\mathbf{X} \pm$ SD & Increased & $P$ value \\
\hline 1. & Initial Measurement $\left(\mathrm{O}_{1}\right)$ & $11,14 \pm 1,9628$ & \multirow{2}{*}{$0,38 \pm 0,34$} & \multirow{2}{*}{0,001} \\
2. & Final Measurement $\left(\mathrm{O}_{2}\right)$ & $11,52 \pm 1,97564$ & & \\
\hline
\end{tabular}

Results of Paired T - Test showed that the value of $p<0.005$, which means the weight changes were statistically significant before and after mentoring with $\mathrm{p}=0.001$.

To see the relationship between respondent participation in nutrition assistance programs and increasing weight children under five, analysis with chisquare test is conducted and the results are as follows: 
Table 7. Relationship Joining Participation Program with Increase of Body Weight Sample

\begin{tabular}{ccccc}
\hline \multirow{2}{*}{ Join the Program } & \multicolumn{2}{c}{ Increase of Body Weight } & \multirow{2}{*}{ Total } & \multirow{2}{*}{$\boldsymbol{P}$ value } \\
\cline { 2 - 3 } & No & Yes & & \\
\hline Not Good & $3(60 \%)$ & $2(40 \%)$ & $5(100 \%)$ & \multirow{2}{*}{$\mathbf{0 . 0 2}$} \\
Good & $0(0 \%)$ & $10(100 \%)$ & $10(100 \%)$ & \\
\hline Total & $\mathbf{3 ( 2 0 \% )}$ & $\mathbf{1 2 ( 8 0 \% )}$ & $\mathbf{1 5 ( 1 0 0 \% )}$ & \\
\hline
\end{tabular}

Table 7 shows that the results obtained by statistical test $p$-value $=0.02(p$ value $\leq 0.05$ ) can be expressed that there is a significant correlation between program participation with children under five weight gain. Children who are good in joining nutrition assistance program will show good results against weight gain, this is because in the process of assisting the process of transferring the knowledge and practical of nutritional care to the respondents, especially mothers as the primary caregivers of children under five.

According Sirajuddin (2007) in his article on "Hearth Model (Stove Model) Proven Ability to Eliminate Malnutrition Case Sustainable", mentions that advantage Hearth method is mothers who have malnourished children learn parenting from their peers whom children are not malnourished. ${ }^{2}$ The potential resource of the family is the mainstay and the sharing of experience is a process of interaction required in this method. Hearth model has two main activities that directly affect the nutritional status change. Both of these activities are (1) The child's cook and eat together with the raw materials from mutual help of the members (2) The child nutrition counseling by official Hearth (Nutrition Assistance Force (TGP), Cadre Health, Hearth Advisor).

From the above explanation it can be concluded that the experience and the process of interaction among peers, share knowledge together are the factor that encourages mothers more capable in parenting practice that has been taught by health facilitators for ongoing nutrition guidance, for a month. Especially experience in cooking together and eating together are monitored directly by the health facilitator and researcher at strengthening phases also experience the process of cooking together in groups to explore the creativity of the group in the development of good nutrition to children in independent phase which is cooking competition. Both of these activity aims to encourage mothers to be able to practice nutrition care which has been thought, either as a group in mentoring sessions and also as individual conducted by counseling method.

In addition to the role of the mother, it also required the support of family which are fathers, brothers or relatives and colleagues and also support from health workers in seeking better nutrition. Furthermore hopefully Indonesian children, as the successor of the nation can grow and develop optimally.

\section{Conclusions and Recommendations}

Nutrition assistance program for children under five which includes parenting a children eating, parenting child hygiene, and parenting of children's health care to the mother/child care provider can increase weight children under five with BGM (under red line in health card). 


\section{Advice}

To overcome malnutrition in children under five:

a. Methods nutrition assistance for one month, then the institution can evaluate for 90 days according to the number of days the management of nutrition.

b. Existence reward for infants and children who experience weight gain.

c. Should be improved education about healthy foods, safe and meets the requirements of balanced nutrition, the importance of good sanitation and hygiene, and how to monitor a child's growth periodically through the neighborhood health center care also prevent and care for sick children at home (home care).

d. Should be good cooperation between mother/care giver, community and agencies to address the nutritional problems.

\section{References}

1. BAPPENAS, Laporan Pencapaian Tujuan Pembangunan Milenium di Indonesia 2010, Jakarta: Kementerian Perencanaan Pembangunan Nasional/Badan Perencanaan Pembangunan Nasional (BAPPENAS), 2010.

2. Sirajuddin, Model Tungku Terbukti Mampu Mengeliminasi Kasus Kurang Gizi Secara Berkelanjutan, Jakarta: Depkes R, http://gizi.depkes.go.id/makalah/download/hearth\%20TT.pdf, 2007. Diakses pada tanggal 07 Februari 2013. 
